\title{
Studi Kasus Pengaruh Logo Halal dan Kesadaran Halal terhadap Keputusan Pembelian Bakso Sapi di Ciawi - Bogor
}

\section{A Study Case of the Effect of Halal Logo and Halal Awareness on Purchasing Decisions of Beef Meatballs in Ciawi - Bogor}

\section{Distya Riski Hapsari1a, Intan Kusumaningrum ${ }^{1}$, Siti Aminah'1, Sri Dewi Puspitasari1}

${ }_{1}^{1}$ Jurusan Teknologi Pangan dan Gizi Fakultas Ilmu Pangan Halal Universitas Djuanda Bogor, Jl. Tol Ciawi No. 1, Kotak Pos 35 Ciawi, Bogor 16720 .

aKorespondensi: Distya Riski Hapsari, E-mail: distya.rizki@unida.ac.id

(Diterima oleh Dewan Redaksi : 9 - 9 - 2019)

(Dipublikasikan oleh Dewan Redaksi : 31 - 10 - 2019)

\begin{abstract}
This study aims to determine the effect of halal logos and halal awareness on purchasing decisions using survei methods, a questionnaire, to Muslim communities in the sub-district. Ciawi-Bogor. Samples taken Ciawi sub-district by using purposive sampling method. The analysis technique is multiple regression analysis. From the results of the study found that: (1) Halal logo had a positive effect on purchasing decisions with a regression value 0.472 and alpha 0.001. (2) Halal awareness had a positive relation on purchasing decisions with a regression value 0.469 and alpha 0.000 . (3) Halal logo and halal awareness had a positive relation on purchasing decisions with alpha of 0,000 , less than $0.05(\mathrm{p}<0.05)$. The regression equation obtained $Y=20.269+0.472 \mathrm{X} 1+0.469 \mathrm{X} 2$. In the second phase of the research, the result showed the sample did not contain borax and formalin.
\end{abstract}

Keywords: halal label, halal awareness, purchasing decisions

\begin{abstract}
ABSTRAK
Penelitian ini bertujuan untuk mengetahui pengaruh logo halal dan kesadaran halal terhadap keputusan pembelian dengan metode survei menggunakan kuesioner pada masyarakat muslim di kecamatan Ciawi-Bogor. Sampel diambil dengan metode purposive sampling. Teknik analisis yang digunakan adalah analisis regresi berganda. Dari hasil penelitian menemukan bahwa: (1) Logo Halal memiliki hubungan positif terhadap keputusan pembelian dengan nilai regresi 0,472 dan alpha 0,001. (2) Kesadaran Halal memiliki hubungan positif terhadap keputusan pembelian dengan nilai regresi 0,469 dan alpha 0,000. (3) Logo halal dan kesadaran halal memiliki hubungan positif terhadap keputusan pembelian dengan alpha 0,000, lebih kecil dari 0,05 $(p<0,05)$. Persamaan regresi yang diperoleh adalah $\mathrm{Y}=20,269+0,472 \mathrm{X} 1+$ 0,469X2. Pada penelitian tahap 2, hasil menunjukkan tidak terdeteksi adanya boraks dan formalin pada sampel bakso kemasan.
\end{abstract}

Kata Kunci: logo halal, kesadaran halal,uji boraks, uji formalin

Hapsari, Distya Riski, Intan Kusumaningrum, Siti Aminah, Sri Dewi Puspitasari. 2019. Studi Kasus Pengaruh Logo Halal dan Kesadaran Halal terhadap Keputusan Pembelian Bakso Sapi di Ciawi - Bogor. Jurnal Agroindustri Halal 5 (2): 196 - 203. 


\section{PENDAHULUAN}

Ciawi merupakan kecamatan yag terletak di kabupaten Bogor dengan penduduk sebanyak 117.000 jiwa (BPS 2017). Penduduk Ciawi mayoritas beragama Islam, dalam agama Islam umat muslim diperintahkan untuk mengkonsumsi makanan yang halal dan thayyib (baik) seperti yang tertera dalam Al Quran surat Al-Baqoroh:168 yang berbunyi. Umat Islam diperintahkan untuk memakan makanan yang halal dan baik yang ada di bumi, oleh karena itu sebagai masyarakat yang beragama Islam dituntut untuk peduli dengan status kehalalan suatu produk sebelum mengonsumsinya.

Bakso merupakan makanan yang cukup digemari oleh masyarakat Indonesia. Namun, bakso yang belum tersertifikasi halal tidak terjamin kehalalannya. Bahan kimia berbahaya seperti boraks dan formalin yang bisa saja ditambahkan pada bakso dapat merugikan orang yang mengonsumsinya. Selain itu, formalin dan bahan berbahaya lainnya , termasuk boraks, telah diharamkan oleh MUI melalui fatwa MUI no. 43 tahun 2012. Oleh karena itu masyarakat dituntut untuk cerdas dalam memilih produk makanan.

Penelitian ini dilakukan untuk mengetahui pengaruh logo halal dan kesadaran halal terhadap keputusan pembelian pada bakso yang dilakukan pada masyarakat Kecamatan Ciawi-Bogor. Pengujian kandungan formalin dan boraks juga dilakukan pada produk bakso kemasan yang dijual di Pasar Tradisional Ciawi.

\section{METODE PENELITIAN}

\section{Bahan dan Alat}

Kuesioner digunakan sebagai alat untuk survei konsumen. Selain itu digunakan untuk pengujian formalin dan boraks. Bahan yang digunakan untuk uji formalin dan boraks dan adalah sampel bakso, aquades, tes kit formalin dan tes kit boraks.

\section{Tempat dan Waktu Penelitian}

Penyebaran kuesioner dilakukan di Ciawi dimana kuesioner disebarkan pada masyarakat Ciawi. Uji kualitatif boraks dan formalin dilakukan di Laboratorium Pengolahan Pangan Universitas Djuanda. Penelitian dilakukan dari April hinggal Juni 2019.

\section{Metode Penelitian}

Penelitian ini dibagi menjadi 2 bagian. Tahap pertama yaitu metode survei penyebaran kuesioner (Gambar 1)

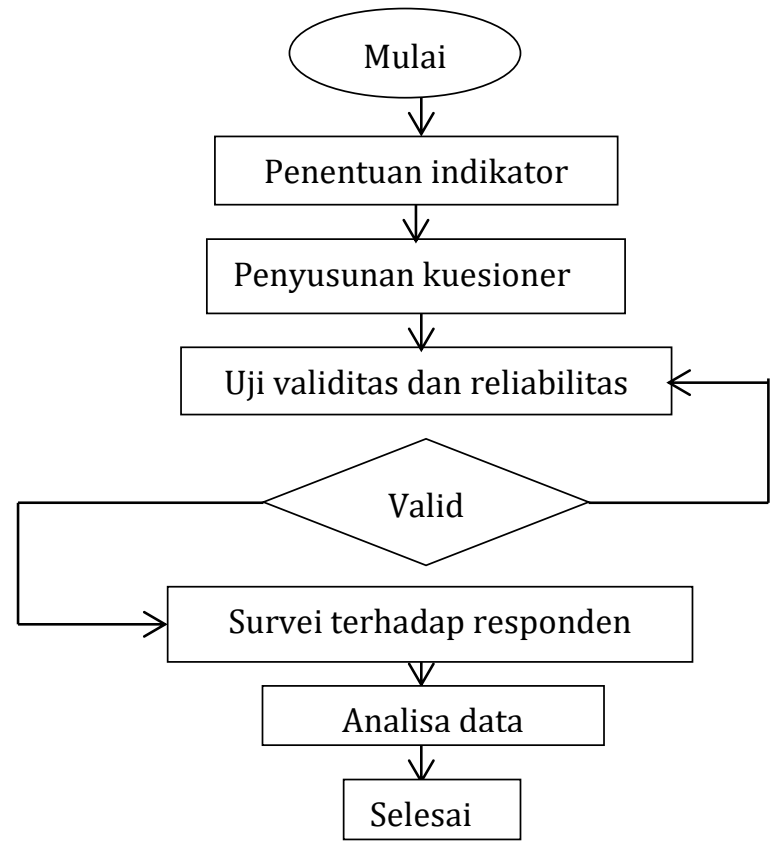

Gambar 1. Diagram alir penelitian kuesioner (Modifikasi Dzulham 2017).

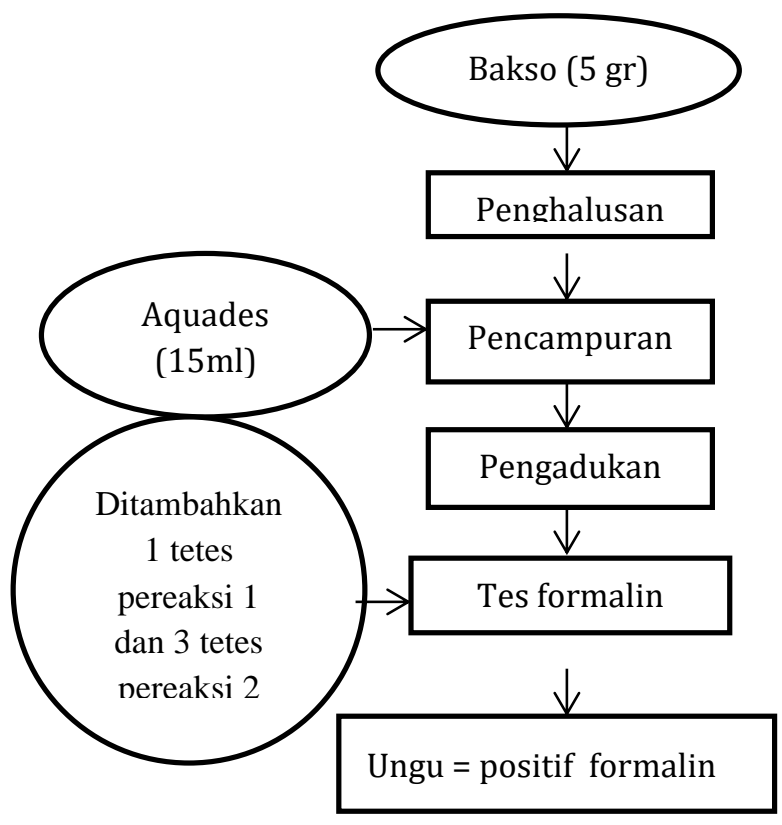

Gambar 2. Diagram alir tes fomalin (modifikasi Yanti 2017) 
Penelitian tahap 2 adalah uji boraks dan formalin menggunakan tes kit. Di bawah ini merupakan cara kerja uji formalin dengan menggunakan tes kit.

Di bawah ini merupakan cara kerja uji boraks dengan menggunakan tes kit.

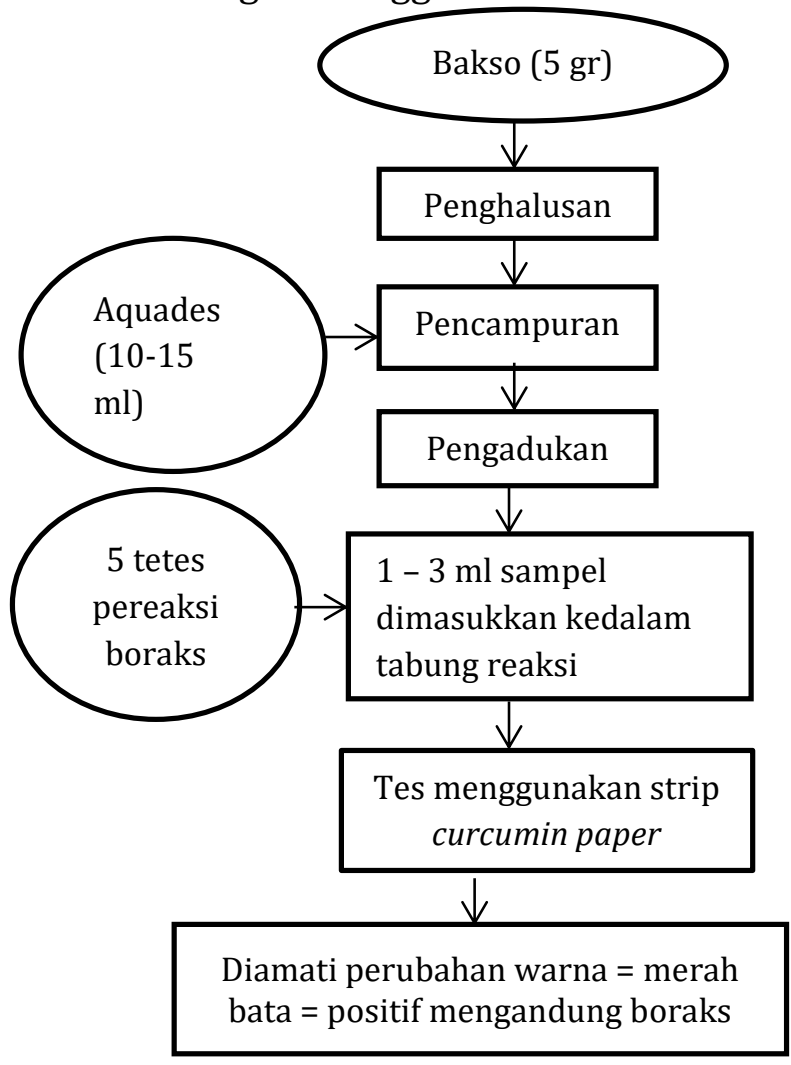

Gambar 3. Diagram alir tes boraks (Modifikasi Widayat 2011)

\section{Populasi dan Sampel}

Populasi adalah masyarakat Kecamatan Ciawi-Bogor. Pengambilan sampel dengan metode purposive sampling. Kriteria responden adalah beragama Islam, berumur lebih dari 18 tahun, pernah membeli produk bakso dalam kemasan, dan merupakan masyarakat kecamatan Ciawi.

Pengambilan sampel dilakukan di kecamatan Ciawi yang terdiri dari 13 desa yaitu desa Banjar Sari, Banjar Wangi, Banjar Waru, Bendungan, Bitung Sari, Bojong Murni, Ciawi, Cibedug, Cileungsi, Citapen, Jambu Luwuk, Pandansari, Teluk Pinang. Sampel diambil sebanyak 100 orang/responden.

\section{Hipotesis}

Variabel yang diteliti terdiri dari variabel terikat dan variabel bebas. Variabel terikat adalah keputusan pembelian (Y) dan variabel bebas terdiri dari logo halal (X1) dan kesadaran halal (X2). Adapun hipotesisnya adalah :

H1: Variabel Logo Halal (X1) berpengaruh secara signifikan terhadap Keputusan Pembelian (Y).

H2: Variabel Kesadaran Halal (X2) berpengaruh secara signifikan terhadap Keputusan Pembelian (Y)

H3: Variabel Logo Halal dan Kesadaran Halal berpengaruh secara simultan atau bersamasama terhadap variabel Y (Keputusan Pembelian)

\section{Definisi Operasional}

Di bawah ini merupakan indikator instrumen penelitian.

Tabel 1. Indikator penelitian

\begin{tabular}{ll}
\hline Variabel & Indikator \\
\hline Logo & -Pengetahuan terhadap \\
halal $\left(\mathrm{X}_{1}\right)$ & logo halal \\
& -Kepercayaan \\
& -Penilaian terhadap label \\
& halal \\
Kesadaran & -Kepedulian mengonsumsi \\
halal $\left(\mathrm{X}_{2}\right)$ & makanan halal \\
& -Pemahaman terhadap \\
& makan-an halal \\
& -Menyadari makanan halal \\
& ada-lah wajib \\
Keputusan & -Pengenalan masalah \\
pembelian & -Pencarian informasi \\
$(\mathrm{Y})$ & -Evaluasi alternatif \\
& -Keputusan pembelian \\
& -Perilaku pasca pembelian \\
\hline
\end{tabular}

Sumber: Modifikasi Waskito (2017), Aziz et al. (2013), Assauri (2004).

\section{Teknik Pengumpulan Data}

Dalam pengumpulan data, peneliti menggunakan metode survei dengan bentuk kuesioner uji skala likert.

\section{Uji Instrumen Penelitian}

Uji validitas, uji reliabilitas, uji normalitas

\section{Analisa Data}

Dilakukan analisis regresi linier berganda, uji $t$ dan uji $f$ dalam menguji hipotesis dan analisa deskriptif 


\section{HASIL DAN PEMBAHASAN}

\section{Gambaran Umum Penelitian}

Bakso yang dikemas dan diedarkan dipasaran harus melalui berbagai pemeriksaan dan pelabelan yang dapat memberikan informasi kepada konsumen untuk membeli, khususunya label halal. Label halal merupakan label yang dikeluarkan oleh MUI ketika suatu produk telah lolos sertifikasi halal. Di bawah ini berbagai merk bakso yang ditemui di pasaran.

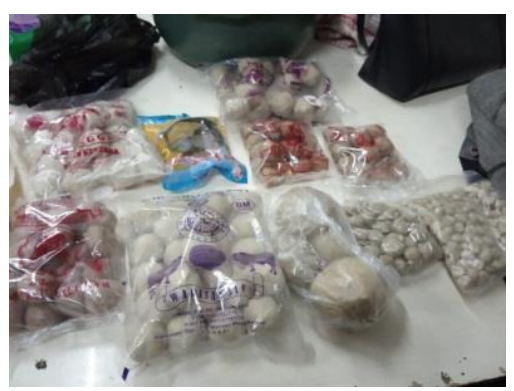

Gambar 4. Berbagai merk bakso

Pada penelitian tahap pertama, dilakukan survei dengan menggunakan kuesioner yang disebarkan pada masyarakat Ciawi yang tersebar di 13 desa. Sampel diambil dari tiap desa sebanyak 5-8 orang. Pada penelitian ini dianalisis seberapa besar logo halal dan kesadaran halal mempengaruhi keputusan pembelian.

Penelitian tahap kedua yang dilakukan adalah menguji formalin dan boraks pada produk bakso daging sapi kemas yang dijual di pasar Tradisional Ciawi. 12 sampel diambil dari berbagai kios dengan merk yang berbeda. Sampel kemudian diuji kemanan pangannya yaitu uji boraks dan formalin dengan menggunakan teskit.

\section{Hasil Uji Validitas}

Responden yang dilibatkan dalam uji validitas adalah sebanyak 30 orang responden. Hasil uji validitas terhadap pernyataan untuk setiap variabel yaitu variabel logo halal (X1) terdiri dari 8 pernyataan valid dan 1 pernyataan tidak valid. Sedangkan keseluruhan variabel kesadaran halal (X2) yang terdiri dari 9 pernyataan dan variabel keputusan pembelian (X3) dengan 13 pernyataan dinyatakan valid. Pernyataan dengan hasil valid digunakan untuk kuesioner selanjutnya dan pernyataan yang tidak valid tidak digunakan.

\section{Hasil Uji Reliabilitas dan Normalitas}

Berdasarkan hasil uji reliabel menghasilkan nilai Alpha cronbrach >0,60 untuk variabel logo halal $(0,918)$, kesadaran halal $(0,881)$, dan minat beli $(0,904)$ sehingga semua instrumen dalam penelitian tergolong reliabel.

Berdasarkan uji normalitas menggunakan teknik Kolmogorov-Smirnov (K-S) distribusi data normal. Signifikansi data $(0,2)$ lebih besar dari 0,05 pada taraf alpha $5 \%$.

\section{Analisis Deskriptif}

Logo halal

Logo halal menjamin kehalalan suatu produk. Logo halal dikeluarkan oleh MUI dan penempatan logo pada kemasan makanan diatur oleh BPOM. Logo halal akan dijadikan pertimbangan oleh konsumen, khususnya yang beragama Islam untuk membeli suatu produk.

Tabel 2. Distribusi frekuensi variabel Logo Halal

\begin{tabular}{llll}
\hline Kategori & Interval skor & $\mathrm{F}$ & $\%$ \\
\hline Tinggi & $\mathrm{X} \geq 35,44$ & 24 & $24 \%$ \\
Sedang & $35,43>\mathrm{X} \geq 30,44$ & 70 & $70 \%$ \\
Rendah & $30,44>\mathrm{X}$ & 6 & $6 \%$ \\
\hline Total & & 100 & $100 \%$ \\
\hline
\end{tabular}

Pada Tabel 2 terlihat bahwa terdapat tiga kategori yaitu kategori tinggi, sedang, dan rendah.

Total skor hasil pernyataan logo halal yang ditanyakan kepada responden menunjukkan total skor kategori sedang dengan frekuensi responden terbanyak yaitu sebesar 70\%. Setelah kategori sedang, kategori tinggi menempati urutan ke dua yaitu dengan frekuensi 1/3 dari frekuensi responden kategori sedang. Responden setuju terhadap pernyataan tentang logo halal seperti Informasi Label Halal LPPOM MUI pada kemasan memperkuat bahwa produk Bakso yang dikemas itu halal, saya percaya bahwa produk yang berlabel halal 
LPPOM MUI menjamin kualitas bahan dan proses produksi, label halal LPPOM MUI menjadi pertimbangan dalam memilih produk olahan daging. Namun, masih ada masyarakat yang tidak tahu tentang logo halal LPPOM MUI. Pengetahuan mengenai logo halal, bentuk logo halal, fungsi logo halal, dan manfaat logo halal merupakan hal yang penting untuk diketahui oleh masyarakat. Pengetahuan akan hal itu dapat memberikan dampak yang baik untuk masyarakat, masyarakat akan lebih mengenal mengenai logo halal resmi dari MUI, mengerti fungsi dan manfaat logo halal, sehingga masyarakat dapat lebih berhati-hati dalam memilih produk bakso.

Kesadaran halal

Kesadaran halal merupakan kesadaran yang ada dalam diri seseorang bahwa orang tersebut mengingat, mengetahui, dan memahami mengenai halal dan membutuhkan produk yang halal sebagai pemenuhan kebutuhan hidupnya (Aziz et al. 2013).

Tabel 3. Distribusi frekuensi variabel Kesadaran Halal

\begin{tabular}{llll}
\hline Kategori & Interval skor & $\mathrm{F}$ & $\mathrm{Pe}$ \\
\hline Tinggi & $\mathrm{X} \geq 40,25$ & 25 & $25 \%$ \\
Sedang & $40,25>\mathrm{X} \geq 34,16$ & 68 & $68 \%$ \\
Rendah & $34,16>\mathrm{X}$ & 7 & $7 \%$ \\
\hline Total & & 100 & $100 \%$ \\
\hline
\end{tabular}

Pada Tabel 3 terlihat terdapat kategori tinggi, sedang, dan rendah. Pada kategori tinggi dengan interval skor yaitu $X>40,25$ dengan jumlah 25 responden. Pada kategori sedang jumlah responden sebanyak 2,72 kali lipat dibandingkan kategori tinggi. Jika dilihat dari persentase kategori sedang dan tinggi dengan jumlah persentase sebanyak 93\%.

Responden tentunya sadar akan halal dan berusaha memenuhi kebutuhannya dengan produk yang halal. Responden menyetujui pernyataan seperti saya sadar bahwa mengkonsumsi makanan halal itu wajib dalam agama islam, saya sadar bahwa makanan yang tidak halal akan mendatangkan mudarat. Namun, masih banyak responden yang tidak peduli karena masih ragu dan kurang percaya terhadap logo halal dan kurangnya pengetahuan halalan thoyyiban.

Keputusan pembelian

Pada variabel keputusan pembelian, peneliti menggunakan lima indikator yaitu :

1. Pengenalan berbagai masalah

2. Pencarian berbagai informasi

3. Evaluasi terhadap alternatifalternatif yang tersedia

4. Keputusan terhadap pembelian

5. Perilaku konsumen pasca pembelian (Kotler dan Keller, 2016).

Kelima indikator tersebut dikembangkan menjadi 13 pernyataan. Di bawah ini merupakan hasil perhitungan distribusi frekuensi variabel Keputusan pembelian.

Tabel 4. Distribusi frekuensi variabel Keputusan Pembelian

\begin{tabular}{llll}
\hline Kategori & Interval skor & $\mathrm{F}$ & $\mathrm{P}$ \\
\hline Tinggi & $\mathrm{X} \geq 56,94$ & 22 & $22 \%$ \\
Sedang & $56,94>\mathrm{X} \geq 49,59$ & 72 & $72 \%$ \\
Rendah & $49,59>\mathrm{X}$ & 6 & $6 \%$ \\
\hline Total & & 100 & $100 \%$ \\
\hline
\end{tabular}

Pada variabel keputusan pembelian, frekuensi responden ada pada kategori sedang dengan jumlah fekuensi yaitu 72, rendah, 22 dan tiggi 6 . Tabel 4 menunjukkan sebagian besar responden berminat memenuhi kebutuhan dengan membeli makanan halal.

\section{Pengujian Hipotesis}

Hasil analisis regresi dapat diketahui bahwa variabel logo halal dan kesadaran halal dapat mempengaruhi minat beli.

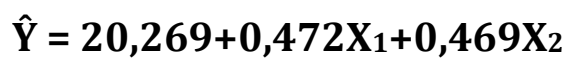

Hipotesis yang diajukan dan dilakukan uji $\mathrm{T}$ adalah hipotesis $\mathrm{H} 1$ dan $\mathrm{H} 2$. $\mathrm{t}$ hitung variabel logo halal $(3,287)$ lebih besar dari $t$ tabel (2,371). Hal ini menunjukkan H0 ditolak, sehingga variabel logo halal memiliki pengaruh secara signifikan terhadap variabel kesadaran halal. Variabel kesadaran halal juga berpengaruh terhadap keputusan pembelian. $t$ hitung variabel kesadaran $(3,991)$ lebih besar dari $t(2,371)$. 
Uji statistik $F$ adalah uji untuk mengetahui apakah semua variabel bebas, X1 dan X2 berpengaruh secara simultan atau bersama-sama terhadap variabel terikat, Y. Apabila nilai F hitung lebih besar dari F tabel, maka dapat disimpulkan bahwa variabel bebas secara simultan berpengaruh terhadap variabel terikat (Y). Dari hasil penelitian dihasilkan bahwa $\mathrm{F}$ hitung $(35,539)$ lebih besar dari $\mathrm{F}$ tabel $(3,09)$ dengan signifikasi 0,000 lebih kecil dari 0,05 sehingga H3 diterima.

\section{Pengaruh logo halal terhadap keputusan pembelian}

Menurut Wandel (1997), sebagian besar konsumen memedulikan dan membaca informasi yang ada pada kemasan makanan. Label menjadi pertimbangan untuk konsumen dalam melakukan pembelian. Minat beli seseorang dapat dipengaruhi dengan adanya sertifikat halal (Shaari et al. 2009). Logo halal pada produk bakso yang dikemas dapat memberikan informasi bahwa produk tesebut halal, aman, dan bersih.

\section{Pengaruh kesadaran halal terhadap minat beli}

Kesadaran halal dapat diketahui berdasarkan pemahaman tentang halal, proses penyembelihan yang benar, dan lebih memilih mengkonsumsi makanan halal (Ahmad et al. 2013). Kesadaran halal merupakan kesadaran yang seharusnya ada pada diri seorang Muslim.

Pada variabel kesadaran halal deskriptif statistik mayoritas berada pada kategori sedang, artinya variabel kesadaran halal dijadikan pertimbangan dalam melakukan pembelian. Kesadaran halal penduduk Ciawi berpengaruh terhadap minat beli bakso. Hal ini selaras dengan penelitian Waskito (2015) mengenai kehalalan terhadap minat beli produk makanan halal Yogyakarta.

\section{Pengaruh logo halal dan kesadaran halal terhadap keputusan pembelian}

Untuk mengetahui pengaruh logo halal dan kesadaran halal dilakukan uji $\mathrm{F}$ dengan hasil t hitung $(35,539)$ lebih besar dari t tabel
$(3,09)$. Hal ini menunjukkan bahwa secara simultan variabel logo halal dan kesadaran halal berpengaruh terhadap keputusan pembelian.

\section{Hasil Uji Boraks dan Formalin}

Uji Formalin

Kegunaan formalin pada penggunaan sehari-hari adalah untuk pembunuh kuman, zat pewarna, pembasmi serangga, pengawet kosmetik, dan lain-lain (Astawan, 2006). Tetapi, formalin sering disalahgunakan pada pembuatan bakso dengan tujuan supaya bakso lebih tahan lama (Damiyati, 2007).

Pada penelitian ini, pengujian formalin dilakukan pada produk bakso yang dijual di kios-kios pasar tradisional Ciawi. Pengujian dilakukan untuk mendeteksi ada tidaknya kandungan formalin pada bakso yang dapat membahayakan konsumen. Pengujian dilakukan pada sampel bakso dengan berbagai merk menggunakan Tes Kit Formalin. Prinsip kerja tes kit formalin adalah adanya reaksi antara formaldehida dan 4-amino-3hidrazino-5-mercapto-1,2.4-Triazole yang membentuk senyawa kompleks berwarna merah ungu. Sampel yang terdeteksi mengandung formalin akan berubah warna menjadi ungu, minimal deteksi pada tes kit adalah 0,5 ppm. Di bawah ini merupakan larutan formaldehyde yang diuji dengan menggunakan teskit.

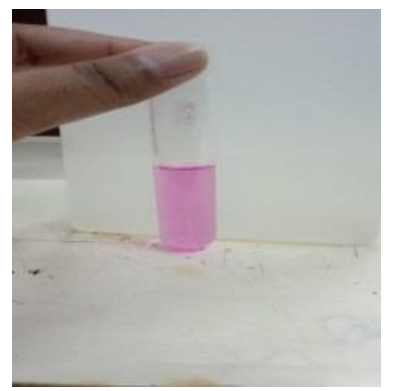

Gambar 5. Sampel standar uji formalin

Di bawah ini merupakan hasil pengujian pada sampel bakso yang dijual di pasar tradisional Ciawi dengan berbagai merk dengan dua kali ulangan. 
Tabel 5. Hasil pengujian formalin pada sampel produk Bakso

\begin{tabular}{llll}
\hline No & Kode Sampel & \multicolumn{2}{c}{ Hasil Uji Tes Kit } \\
\cline { 3 - 4 } & & Ulangan 1 & Ulangan 2 \\
\hline 1 & Bakso A & - & - \\
2 & Bakso B & - & - \\
3 & Bakso C & - & - \\
4 & Bakso D & - & - \\
5 & Bakso E & - & - \\
6 & Bakso F & - & - \\
7 & Bakso G & - & - \\
8 & Bakso J & - & - \\
9 & Bakso K & - & - \\
10 & Bakso L & - & - \\
11 & Bakso M & - & - \\
12 & Bakso N & - & - \\
\hline
\end{tabular}

Keterangan : tanda strip (-) menunjukkan formalin tidak terdeteksi pada sampel.

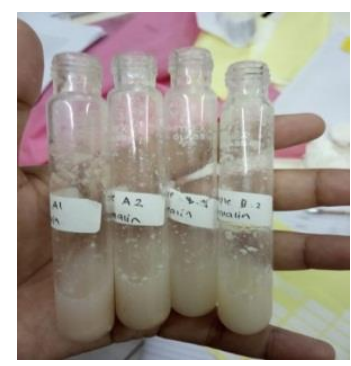

Gambar 6. Hasil pengujian sampel produk bakso

Dari hasil pengujian dapat dilihat pada Tabel 5 bahwa semua sampel produk bakso negatif atau tidak terdeteksi adanya formalin. Hasil uji negatif ditandai dengan tidak adanya perubahaan warna yang terlihat pada tabung reaksi, dimana sampel bakso masih tetap berwarna kecoklatan dan tidak ada perubahan menjadi warna ungu.

\section{Uji Boraks}

Boraks merupakan senyawa kimia dengan warna natrium hidroksida dan asam borat. Penggunaan boraks banyak disalahgunakan terutama dalam pembuatan makananan seperti kerupuk, mie, lontong, ketupat, maupun bakso. Boraks lebih tepat digunakan dalam dunia industri non pangan seperti antiseptik, pengontrol kecoa, pengawet kayu, bahan pembersih (Suhanda, 2012). Gangguan otak, hati, dan ginjal merupakan sebagian akibat dari mengkonsumsi makanan berboraks. Dalam jumlah banyak, boraks menyebabkan gangguan pada kesehatan seperti demam, tekanan darah turun, apatis, pingsan, anuria, menimbulkan depresi, sianosis, koma, bahkan kematian (Nasution, 2009). Menurut Damiyati (2007), fungsi boraks pada bakso adalah untuk memperbaiki tekstur dan mengenyalkan.

Pada penelitian ini, pengujian boraks dilakukan dengan menggunakan Tes Kit Boraks. Minimal deteksi adalah 2 ppm boraks. Tes kit boraks yang terdiri dari pereaksi dan curcumin paper. Prinsip uji cepat boraks adalah reaksi boron dan kurkumin mebentuk senyawa rososianin yang berwarna merah. Sampel yang mengandung boraks akan menyebabkan perubahan warna pada curcumin paper menjadi merah atau merah bata.

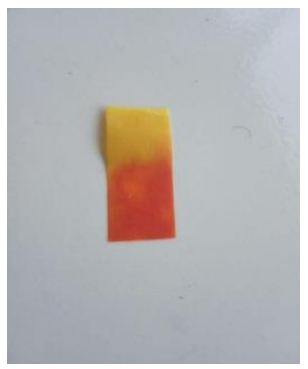

Gambar 7. Sampel standar uji boraks

Tabel 6. Hasil pengujian boraks pada sampel produk bakso

\begin{tabular}{llll}
\hline No & Sampel & \multicolumn{2}{l}{ Hasil Uji Tes Kit } \\
\cline { 3 - 4 } & & Ulangan 1 & Ulangan 2 \\
\hline 1 & Bakso A & - & - \\
2 & Bakso B & - & - \\
3 & Bakso C & - & - \\
4 & Bakso D & - & - \\
5 & Bakso E & - & - \\
6 & Bakso F & - & - \\
7 & Bakso G & - & - \\
8 & Bakso J & - & - \\
9 & Bakso K & - & - \\
10 & Bakso L & - & - \\
11 & Bakso M & - & - \\
12 & Bakso 0 & - & - \\
\hline
\end{tabular}

Keterangan : tanda strip (-) menunjukkan boraks tidak terdeteksi pada sampel. 


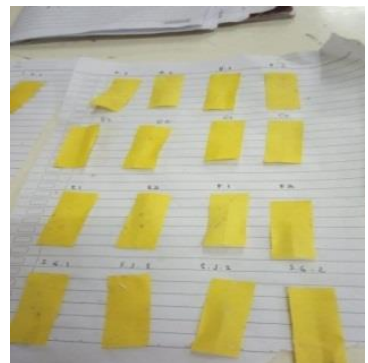

Gambar 6. Hasil uji boraks pada sampel bakso

Dari tabel dan gambar di atas, menunjukkan bahwa sampel yang diuji tidak terdeteksi adanya boraks karena curcumin paper tidak ada perubahan warna menjadi merah maupun merah bata.

\section{KESIMPULAN}

Dari hasil penelitian ini dapat disimpulkan bahwa masing - masing atau secara simultan, variabel logo halal dan kesadaran halal berpengaruh positif terhadap keputusan pembelian. Masyarakat Ciawi dalam melakukan pembelian mempertimbangkan logo halal dan kesadaran halal. Pada penelitian tahap dua, pengujian sampel boraks dan formalin pada produk bakso yang dijual di pasaran dihasilkan bahwa boraks dan formalin tidak terdeteksi pada tes kit.

\section{DAFTAR PUSTAKA}

Ahmad NA, Abaidah TNT, Yahya MHA. 2013. A study on halal food awareness among Muslim customers in Klang. In : 4th International Conference on Business and Economic Research Proceeding, Bandung. Pp. 1073-1087.

Assauri S. 2004. Manajemen Pemasaran. Rajawali press, Jakarta.

Astawan M. 2004. Tetap Sehat dengan Produk Makanan Olahan. Tiga Serangkai, Solo.

Aziz, Abdul Y, Vui CN. 2012. The role of Halal awareness and Halal certification in influencing non Muslim"s purchasing intention. In: Paper presented at 3rd International Conference on Business and Economic Research (3rd ICBER 2012). pp. 1819-1830.
[BPS] Badan Pusat Statistika. 2018. Kecamatan Ciawi dalam Angka [internet]. Tersedia pada: https://bogorkab.bps.go.id [18 Februari 2019]

Damiyati N. 2007. Ada Pengenyal Bakso selain Boraks. http://www.pikiranrakyat.com. [18 Februari 2019]

Kotler and Keller. 2016. Marketing Management 16 edition. Pearson, New Jersey

Lembaga Pengkajian Pangan Obat-obatan dan Kosemetika Majelis Ulama Indonesia. Pedoman Pemenuhan Kriteria Sistem Jaminan Halal di Restoran (HAS 23102) [Internet]. Tersedia pada: www. halalmui. org [15 Februari 2019]

Nasution A. 2009. Analisa kandungan boraks pada lontong di kelurahan Padang Bulan kota Medan Tahun 2009 [Skripsi]. Universitas Sumatera Utara, Medan.

Suhanda R. 2012. Higiene sanitasi pengolahan dan analisa boraks pada bubur ayam yang dijual di kecamatan Medan Sunggal [Skripsi]. Universitas Sumatera Utara, Medan.

Wandel M. 1997. Food labeling from a consumer perspective. British Food Journal, MCB University Press (6): 99

Waskito D. 2015. Pengaruh sertifikasi halal, kesadaran halal, dan bahan makanan terhadap minat beli produk makanan halal Yogyakarta [Skripsi]. Fakultas Ekonomi, Universitas Negeri Yogyakarta, Yogyakarta.

Widayat D. 2011. Kandungan boraks pada bakso (studi pada warung bakso di kecamatan Sumbersarikabupaten Jember [skripsi]. Universitas Kesehatan Masyarakat, Jember.

Yanti, E. 2017. Studi kasus kandungan boraks dan formalin pada bakso dan tahu dilingkungan sekolah kecamatan Lubuklinggau Barat di kota Lubuklinggau [skripsi]. STKIP PGRI, Lubuklinggau. 